\title{
Factors Affecting Rain Infiltration on a Slope Using Green-Ampt Model
}

\author{
Agus Setyo Muntohar ${ }^{* *}$ and Hung-Jiun Liao² \\ ${ }^{1}$ Department of Civil Engineering, Universitas Muhammadiyah Yogyakarta, \\ Jl. Brawijaya, Tamantirto, Bantul, D.I. Yogyakarta, 55183I, Indonesia \\ ${ }^{2}$ Department of Civil and Construction Engineering, National Taiwan University \\ of Science and Technology, No.43, Keelung Rd., Sec.4, Taipei 10607, Taiwan \\ *Corresponding author: muntohar@umy.ac.id
}

Published online: 25 November 2019

To cite this article: Muntohar, A. S. \& Liao, H-J. (2019). Factors affecting rain infiltration on a slope using Green-Ampt model. J. Phys. Sci., 30(3), 71-86, https://doi.org/10.21315/ jps2019.30.3.5

To link to this article: https://doi.org/10.21315/jps2019.30.3.5

\begin{abstract}
Rainwater infiltration into the ground is liable for the rising of transient pore water pressure during rainfall. Due to the significant role of infiltration in controlling slope failure, this study aims to investigate the factors affecting the rainwater infiltration during extreme rainfall. Parametric studies on the Green-Ampt infiltration model were performed to evaluate the effect of the parameters such as soil type, moisture-suction and slope angle. In this study, a new parameter $\left(M_{\psi}\right)$ was introduced as moisture-suction as the product of the suction head at the wetting front, and volumetric water content deficit. Rainfall condition has been collected from three typhoons attacking Taiwan in July 2006. The results showed that the increase in saturated hydraulic conductivity and moisturesuction parameter could increase the infiltration rate. The infiltration decreases with the increase of the slope angle of the surface. For slope made of high permeability soil, the significant variation in moisture-suction has changed the infiltration rate considerably compared with the slope covered with the lower permeability material. This study proposes a new graphical aid to represent the basic Green-Ampt equation for the sloping of various gradients. Comparing the infiltration for sloping surface and horizontal surface, the reduction of infiltration rate is given by $k_{\text {sat }}(1-\cos \beta)$.
\end{abstract}

Keywords: Rain infiltration, Green-Ampt model, sloping surface, typhoons, hydraulic conductivity 


\section{INTRODUCTION}

Landslide is a worldwide disaster that has received considerable attention from many researchers, investigating its triggering and causative factors and mechanisms. Here, rainfall is widely known as the major triggering factor of landslides. Landslides in various types, e.g., shallow and deep, occasionally occur during the typhoon season and heavy rainfall periods in Taiwan. It is related to the landslides by ways of rain infiltration into the ground and the consequent rising of transient pore water pressure during rainfall. Research indicated that the saturation initiated slope failure on the slope surface. Then, the saturation would advance to wetting-front depth during an intense rainfall. ${ }^{1,2}$ Hence, the initiation of saturation can be determined by a preliminary analysis of slope failure corresponding to landslide occurrence. However, estimating the rain infiltration is by no means a straightforward problem in the natural slopes. Many efforts have been attempted to quantify the rain infiltration behaviour. Of the models used for rain infiltration analysis, Green-Ampt infiltration model, by far, is the most commonly used one. The Green-Ampt model is relatively simple; however, it can generate results that are in good agreement with other more rigorous infiltration models such as Richard's equation, Philip's model, and numerical method. ${ }^{3-5}$ Several studies have modified the Green-Ampt model for improving the estimation of soil water infiltration and redistribution for a wide range of soils and layered soils. ${ }^{6-8}$

The Green-Ampt model is a simplified representation of the infiltration process that assumes that the ground surface is horizontal. In other words, the original GreenAmpt model is not applied to the sloping surface. However, until recently, it is still used by many researchers, properly or improperly, to quantify the rain infiltration factors and input them to the slope stability analysis., ${ }^{1,2,9-11}$ To better quantify the rain infiltration on a sloping surface, this paper proposes a modified Green-Ampt model to account for the influence of sloping ground surface. A parametric study is carried out by using the modified Green-Ampt model to evaluate the effect of the sloping surface on rain infiltration. The discussion of this paper are focused on the effect of slope steepness, hydraulic conductivity, and the moisture-suction characteristics of soil in the infiltration process under heavy rainfall condition. In addition, this study proposes a new graphical aid to represent the basic Green-Ampt equation for the sloping grounds of various gradients. This non-dimensional new graph is a quick method and practicable to evaluate infiltration potential for the sloping surface. Furthermore, the graph can be extended to evaluate the landslide potential of a slope by determining the surface saturation. 


\section{GREEN-AMPT INFILTRATION MODEL}

The Green-Ampt model has been extensively used to estimate the infiltration process during both steady and unsteady rainfall events and layered soils. ${ }^{12-14}$ The basic Green-Ampt infiltration equations for the horizontal surface are written in Equations 1 and 2:15

$$
\begin{aligned}
& f(t)=k_{\text {sat }}\left[1+\frac{\left(\psi_{f} \cdot \Delta \theta\right)}{F(t)}\right] \\
& F(t)=\left(\psi_{f} \cdot \Delta \theta\right) \ln \left[1+\frac{F(t)}{\left(\psi_{f} \cdot \Delta \theta\right)}\right]=k_{\text {sat }} \cdot t
\end{aligned}
$$

Equations 1 and 2 do not account for the influence of slope steepness. To take into account the inclination of the sloping ground surface, modified the Green-Ampt equations as in Equations 3 and 4: ${ }^{15}$

$$
\begin{aligned}
& f(t)=k_{\text {sat }}\left[\cos \beta+\frac{\left(\psi_{f} \cdot \Delta \theta\right)}{F(t)}\right] \\
& F(t)-\frac{\left(\psi_{f} \cdot \Delta \theta\right)}{\cos \beta} \ln \left[1+\frac{F(t) \cos \beta}{\left(\psi_{f} \cdot \Delta \theta\right)}\right]=k_{y} \cdot t
\end{aligned}
$$

where $f(t)=$ infiltration rate at time $t, F(t)=$ cumulative infiltration at time $t$, $\psi_{f}=$ suction head at wetting front, $\Delta \theta=$ volumetric water content deficit $\left(=q_{s}-q_{i}\right), \beta=$ slope angle, $k_{y}=k_{\text {sat. }} \cos \beta$, and $k_{\text {sat }}=$ saturated hydraulic conductivity. For horizontal surface where $\beta=0$ and $\cos \beta=1$, Equations 3 and 4 become the same as Equations 1 and 2. Equation 3 shows that the increasing slope angle reduces the infiltration rate. This equation is in agreement with the field infiltration test done previous researchers. ${ }^{16,17}$ From Equations 1 and 3, the reduction of infiltration rate can be expressed as:

$$
\begin{aligned}
& f(t)_{\beta=0}-f(t)_{0<\beta<90}=k_{\text {sat }}(1-\cos \beta) \\
& k_{\text {sat }}\left[1+\frac{\left(\psi_{f} \cdot \Delta \theta\right)}{F(t)}\right]-k_{\text {sat }}\left[\cos \beta+\frac{\left(\psi_{f} \cdot \Delta \theta\right)}{F(t)}\right]=k_{\text {sat }}(1-\cos \beta)
\end{aligned}
$$

Equations 5 and 6 can be solved by considering three types of rain infiltration that were possible during a rainfall event as shown in Figure 1. ${ }^{18,19}$ In Case 1, the rainfall intensity was greater than the infiltration rate, and saturation on the ground surface occurred at this time interval. For Case 2, the rainfall intensity was initially 
less than the infiltration rate at the beginning of the precipitation. At a later stage, the intensity became larger than the water infiltration rate, and the ground surface changed from being unsaturated to be saturated. Moreover, in Case 3, there was no surface saturation in this time interval. For Case 3, all rainfall infiltrated into the soil since the rainfall intensity was less than the infiltration rate.

Surface saturation occurs only if the potential infiltration rate becomes less than the rainfall intensity. Hence, the infiltrated rainfall can be calculated using Equation 7:

$$
F(t+\Delta t)-F(t)-\frac{\left(\psi_{f} \cdot \Delta \theta\right)}{\cos \beta} \cdot \ln \left[\frac{\left(F(t+\Delta t) \cos \beta+\psi_{f} \cdot \Delta \theta\right)}{\left(F(t) \cos \beta+\psi_{f} \cdot \Delta \theta\right)}\right]=k_{y} \Delta t
$$

After surface saturation, any additional rainfall will become the surface run-off. If Case 2 occurs, the time needed to reach saturation is defined as in Equation 8:

$$
t_{p}^{\prime}=\frac{F\left|t_{p}^{\prime}\right|-F(t)}{I(t)}
$$

Thus, the infiltrated rainfall can be calculated using the following equation:

$$
F\left(t_{p}^{\prime}\right)=\frac{k_{s a t}\left(\psi_{f} \cdot \Delta \theta\right)}{I(t)-k_{s a t} \cos \beta}
$$

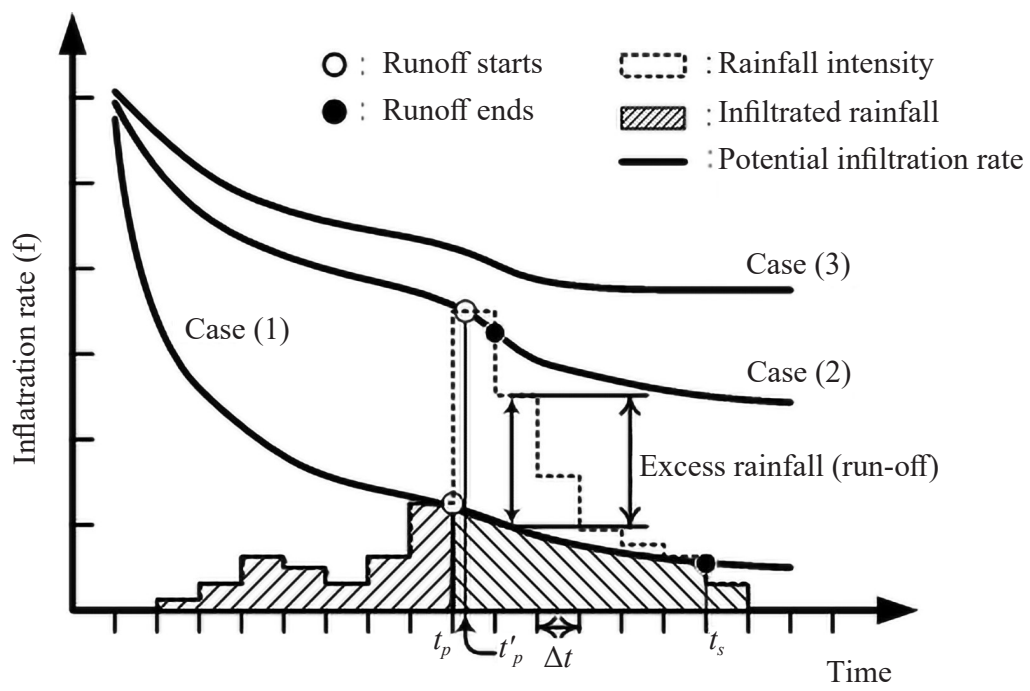

Figure 1: Typical of infiltration and excess rainfall under unsteady rainfall (modified from Chu. $\left.{ }^{13}\right)$. 
Equations 3 and 4 need iteration to carry out the calculation of unsteady rainfall. Hence, the equations are re-written as dimensionless variables with different implicit forms as given in Equations 10 and 11.

$$
\frac{f(t)}{k_{\text {sat }}}=\left(\cos \beta+\frac{1}{F_{t}^{*}}\right)=f_{t}^{*}
$$

From Equation 4, the normalised cumulative infiltration can be written as:

$$
\frac{F(t)}{\left(\psi_{f} \cdot \Delta \theta\right)}=\cos ^{-1} \beta \cdot \ln \left[1+\frac{F(t)}{\left(\psi_{f} \cdot \Delta \theta\right)} \cos \beta\right]+\frac{k_{y} \Delta t}{\left(\psi_{f} \cdot \Delta \theta\right)}=F_{t}^{*}
$$

where $f_{t}^{*}$ and $F_{t}^{*}$ are the normalised infiltration rate and cumulative infiltration for the unsteady rainfall, respectively. Both $f_{t}^{*}$ and $F_{t}^{*}$ are dimensionless. Both $\psi_{f}$ and $\Delta \theta$ are closely correlated. Hence, these two parameters can be expressed as a single parameter of moisture-suction $\left(M_{\psi}\right)$.

\section{DATA AND ANALYSIS}

\subsection{Location of Study and Rainfall Record}

In this study, the precipitations were recorded from three rain gauges installed along the T-18 mountain road in Central Taiwan at the mileages of $27 \mathrm{~K}+200$, $56 \mathrm{~K}+200$ and $64 \mathrm{~K}+800$ (Figure 2). Three typhoons that attacked Taiwan in July 2006 were chosen as the rainfall events for infiltration analysis including Ewiniar (7-9 July 2006), Bilis (13-16 July 2006) and Kaemi (23-26 July 2006). The hourly rainfall and accumulated rainfall for each typhoon recorded at mileage $27 \mathrm{~K}+200$ are shown in Figure 3. Of the three typhoons, Typhoon Bilis brought in an intense rainfall with the accumulated rainfall approaching $800 \mathrm{~mm}$, and the maximum rainfall intensity reaching $51.5 \mathrm{~mm} \mathrm{~h}^{-1}$. In comparison, the recorded accumulated rainfalls for the other two typhoons were around $400 \mathrm{~mm}$ and $200 \mathrm{~mm}$ for Typhoon Ewiniar and Typhoon Kaemi, respectively.

\subsection{Green-Ampt Parameters}

The parameters used in the Green-Ampt model included the $\Delta \theta, \psi_{f}$ and $k_{s a t}$. The saturated hydraulic conductivity and suction are known as the inherent parameters for soil. Those parameters can be obtained from the laboratory or field tests. Table 1 summarises the range of Green-Ampt parameters for various soil textures (United State Department of Agriculture classification). It can be found that disparities in parameter $\psi_{f}$ were enormous for the soils chosen in this study. For the input to the Green-Ampt model, the moisture-suction parameter is shown in Table 2. 


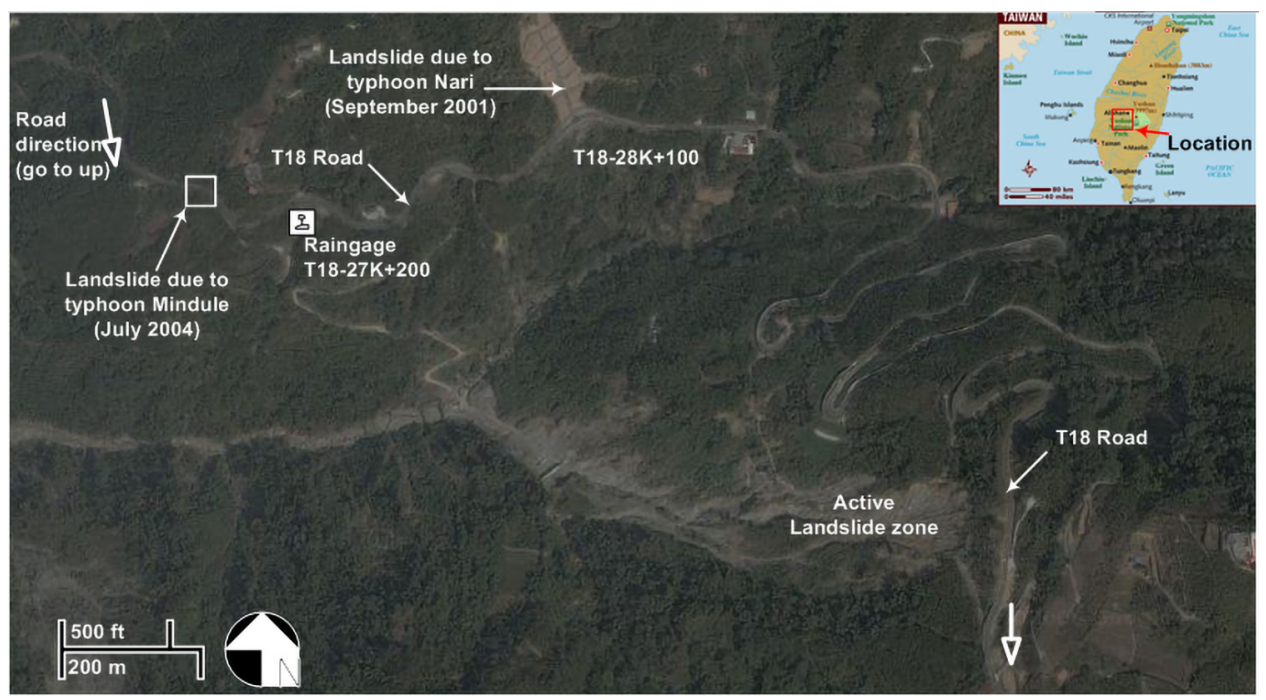

Figure 2: Location of study and rain gauge at T18 road.
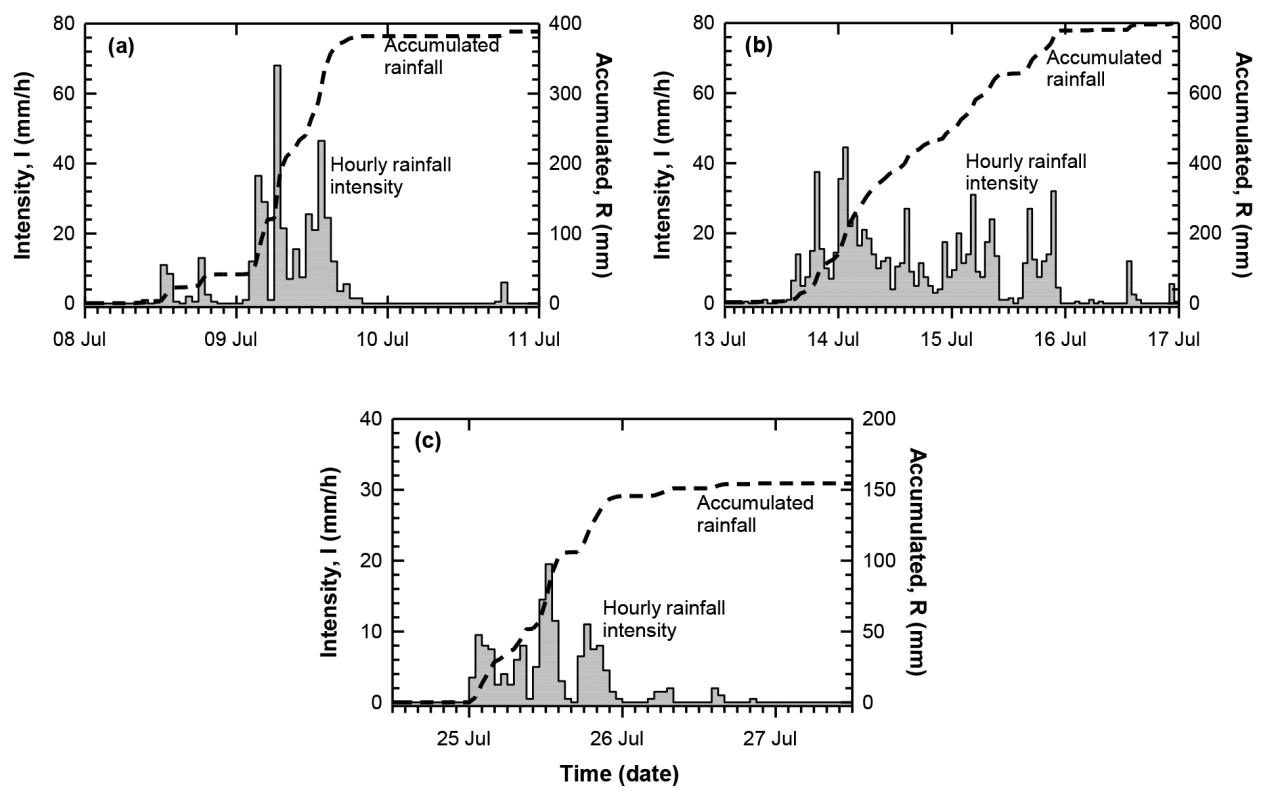

Figure 3: Rainfall hyetograph in July 2006 illustrating three typhoons attacked Taiwan: (a) Ewiniar, (b) Bilis, and (c) Kaemi, at mileage $27 \mathrm{~K}+200$ along T18 road. 
Table 1: Green Ampt infiltration parameters for typical soils. ${ }^{20}$

\begin{tabular}{lcccccc}
\hline Soil type & $\eta$ range & $\theta_{e}$ range & $\begin{array}{c}\text { Range of } \psi_{f} \\
(\mathrm{~mm})\end{array}$ & $\begin{array}{c}k \\
\left(\mathrm{~mm} \mathrm{~h}^{-1}\right)\end{array}$ & $\begin{array}{c}\psi_{f} \\
(\mathrm{~mm})\end{array}$ & $\begin{array}{c}k_{\text {sat }} \\
\left(\mathrm{mm} \mathrm{h}^{-1}\right)\end{array}$ \\
\hline Sand & $0.374 \sim 0.5$ & $0.354 \sim 0.48$ & $9.7 \sim 253.6$ & 117.8 & 49.5 & 235.6 \\
Loamy sand & $0.363 \sim 0.506$ & $0.329 \sim 0.473$ & $13.5 \sim 279.4$ & 29.9 & 61.3 & 59.8 \\
Sandy loam & $0.351 \sim 0.555$ & $0.283 \sim 0.541$ & $26.7 \sim 454.7$ & 10.9 & 110.1 & 21.8 \\
Loam & $0.375 \sim 0.551$ & $0.334 \sim 0.534$ & $13.3 \sim 593.8$ & 3.4 & 88.9 & 6.8 \\
Silt loam & $0.42 \sim 0.582$ & $0.394 \sim 0.578$ & $29.2 \sim 953.9$ & 6.5 & 466.8 & 13 \\
Sandy clay loam & $0.332 \sim 0.464$ & $0.235 \sim 0.425$ & $44.2 \sim 1080$ & 1.5 & 218.5 & 3 \\
Clay loam & $0.409 \sim 0.519$ & $0.279 \sim 0.501$ & $47.9 \sim 911$ & 1 & 208.8 & 2 \\
Silty clay loam & $0.418 \sim 0.524$ & $0.347 \sim 0.517$ & $56.7 \sim 1315$ & 1 & 273 & 2 \\
Sandy clay & $0.37 \sim 0.49$ & $0.207 \sim 0.435$ & $40.8 \sim 1402$ & 0.6 & 239 & 1.2 \\
Silty clay & $0.425 \sim 0.533$ & $0.334 \sim 0.512$ & $61.3 \sim 1394$ & 0.5 & 292.2 & 1 \\
Clay & $0.427 \sim 0.523$ & $0.269 \sim 0.501$ & $63.9 \sim 1565$ & 0.3 & 316.3 & 0.6 \\
\hline
\end{tabular}

Notes: $\eta=$ the soil porosity; $\theta_{e}=$ effective moisture content; $\psi_{f}=$ suction head at wetting front; $k=$ hydraulic conductivity; $k_{\text {sat }}=$ saturated hydraulic conductivity $=2 k$

Table 2: The Green-Ampt parameters used in this study

\begin{tabular}{cccc}
\hline Soil type & $k_{\text {sat }}\left(\mathrm{mm} \mathrm{h}^{-1}\right)$ & $M_{\psi}{ }^{\mathrm{a}}(\mathrm{mm})$ & Degree of permeability \\
\hline 1 & $360\left(1 \times 10^{-4}\right)$ & $30,120,240,360$ & Higher \\
2 & $36\left(1 \times 10^{-5}\right)$ & $30,120,240,360$ & $\underset{\text { Lower }}{ }$ \\
3 & $3.6\left(1 \times 10^{-6}\right)$ & $30,120,240,360$ & \\
4 & $0.36\left(1 \times 10^{-7}\right)$ & $30,120,240,360$ & \\
\hline
\end{tabular}

Notes: Values in the brackets are in $\mathrm{m} \mathrm{s}^{-1} ;{ }^{a} \Delta \theta=0.3$

\subsection{Simulation Procedure}

Slope angle was varied from $0^{\circ}$ to $70^{\circ}$ to study the effect of slope steepness on the infiltration process. The rain infiltration was calculated using Equations 3 to 10 as proposed by Chow et al. ${ }^{21}$ Then, the computation algorithm was resolved by the model of Muntohar and Liao. ${ }^{18,19}$ The simulation included evaluating whether the surface run-off would occur in a rainfall event based on the relative values of infiltration rate $f(t)$ and rainfall intensity $I(t)$ at time $t$. For the Case 1 as shown in Figure $1, f(t)$ was equal to or smaller than $I(t)$, indicating that the ground surface saturated. Rainfall with this intensity would not only infiltrate into the ground but also generate surface run-off. For Case 2, $f(t)$ was larger than $I(t)$. It indicated that the soil surface would remain unsaturated under this rain condition (Case 3). However, for Case 2, the ground surface would become saturated some time between $t_{n}$ and $t_{n}+\Delta t$ interval although it was not yet saturated at time $t_{n}$. 


\section{RESULTS AND DISCUSSION}

\subsection{Infiltration Response}

Figure 4 shows the typical infiltration rate for soils with $k_{\text {sat }}=36 \mathrm{~mm} \mathrm{~h}^{-1}$, $M_{\psi}=30 \mathrm{~mm}$, and for slopes with angle $\beta=0^{\circ}$ to $70^{\circ}$. The infiltration rates for soils with $k_{\text {sat }}=18 \mathrm{~mm} \mathrm{~h}^{-1}, 36 \mathrm{~mm} \mathrm{~h}^{-1}$ and $72 \mathrm{~mm} \mathrm{~h}^{-1}$ were compared as shown in Figure 4(a). The first feature of the typical infiltration (Figure 4) showed that the infiltration rate declined with elapsed time. Once the surface saturated, surface runoff started, and infiltration capacity decreased over time until reaching the minimum infiltration capacity. In the Green-Ampt model, the infiltration capacity was assumed to be equal to soil hydraulic conductivity at the saturated condition. For example, the soil with hydraulic conductivity at saturated condition $\left(k_{\text {sat }}\right)$ equal to $18 \mathrm{~mm} \mathrm{~h}^{-1}$, and then the infiltration rate of the soil would drop to $18 \mathrm{~mm} \mathrm{~h}^{-1}$ at the end, shown in Figure 4(a). If the rainfall intensity was lesser than the infiltration capacity $\left(I(t)<k_{\text {sat }}\right)$, then all the rainfall infiltrated into the soil, and no run-off occurred. During typhoon Ewiniar (8-10 July 2006), rainfall was completely infiltrated into the subsurface soil if $k_{\text {sat }}$ was equal to $72 \mathrm{~mm} \mathrm{~h}^{-1}$.
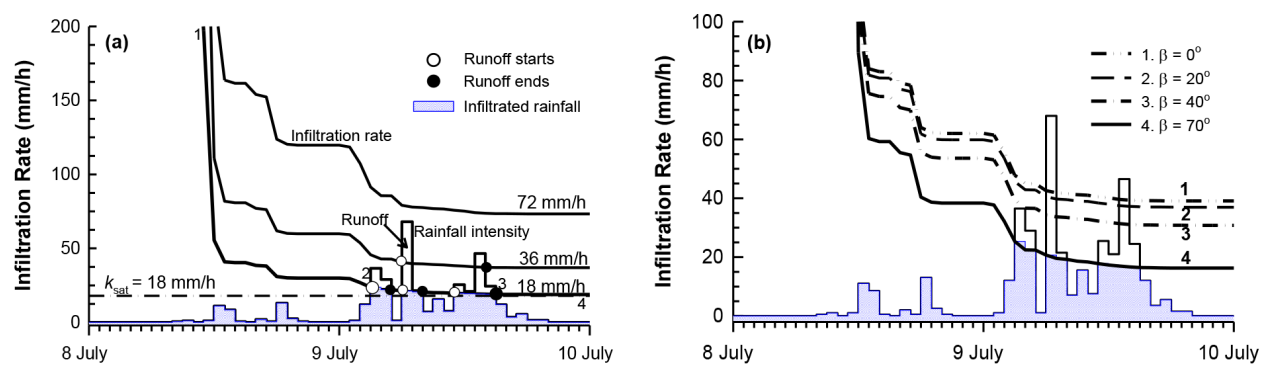

Figure 4: Illustrations of (a) typical infiltration rate for unsteady rainfall for $\beta=20^{\circ}$ with various $k_{\text {sat }}$, and (b) effect of slope angle for $k_{\text {sat }}=36 \mathrm{~mm} \mathrm{~h}^{-1}$.

The second feature of the infiltration figure was to identify the moment when the rainfall intensity was greater than the saturated hydraulic conductivity, $I(t)>k_{s a t}$. The rainfall intensity above the curve of infiltration rate resulted in a surface runoff. As shown in Figure 4(a), the white points on the infiltration curve stand for the time when the run-off starts; the black points stand for the time when the run-off stops. So, the shaded area from point 2 to 3 below the curve of infiltration rate represents the amount of rainwater infiltrating into the ground. In this case, the surface would saturate if the $f(t)=I(t)=k_{\text {sat }}$.

The third feature of the infiltration figure was to determine the time when the surface began to be saturated or the time to start run-off $\left(t_{p}\right)$. Time to saturation can 
be continued till the end of rainfall if the rainfall intensity remains smaller than $k_{\text {sat }}$. A soil with $k_{\text {sat }}=18 \mathrm{~mm} \mathrm{~h}^{-1}$ reached saturation earlier than the soil with $k_{\text {sat }}=$ $36 \mathrm{~mm} \mathrm{~h}^{-1}$. This feature explicated that soil with a lower permeability would get saturated earlier than a soil with a higher permeability at the same moisture-suction condition. Infiltration rate decreased with the increase in slope angle as shown in Figure 4(b). This behaviour is in agreement with the field infiltration experiments carried out by Lu et al. ${ }^{16}$ Lower infiltration rate on the steeper slope is caused by higher flow velocities and shorter detention time of rainwater on the steeper surface. ${ }^{17}$ Theoretically, a more prolonged detention time increases the surface water storage and results in higher infiltration rate.

Figure 5 presents a graphical aid to represent the infiltration rate and cumulative infiltration as depicted by Equations 10 and 11. Correlation between these equations shows a unique relationship. The infiltration decreases with the increasing slope angle of the surface. However, beyond point $P$ (inset graph in Figure 5), the rain infiltration does not change significantly with the slope angle as all the rainwater infiltrates into subsurface layer if the rain infiltration rate goes beyond point $\mathrm{P}$. Comparing the infiltration rate of horizontal surface $\left(\beta=0^{\circ}\right)$ and sloping surface $\left(\beta>0^{\circ}\right)$, hence, using Equations 5 and 6 for slope with $\beta=70^{\circ}$, the infiltration rate reduced by $66 \%$ compared to that of the horizontal surface $\left(\beta=0^{\circ}\right)$. Comparing the infiltration for sloping surface and horizontal surface, the reduction of infiltration rate is given by $k_{s a t}(1-\cos \beta)$.

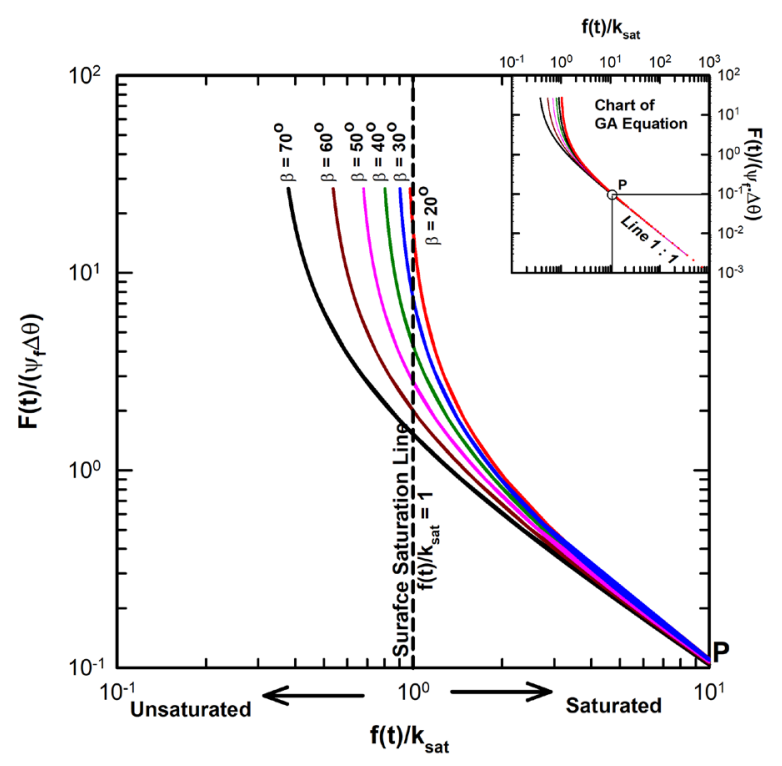

Figure 5: Representation chart of the Green-Ampt equation on a sloping surface. 


\subsection{Effect of Saturated Hydraulic Conductivity}

The $k_{\text {sat }}$ of soil changes with soil types. For a sandy soil, the $k_{\text {sat }}$ is commonly larger than $360 \mathrm{~mm} \mathrm{~h}^{-1}\left(10^{-4} \mathrm{~m} \mathrm{~s}^{-1}\right)$, while the $k_{\text {sat }}$ is lower than $0.36 \mathrm{~mm} \mathrm{~h}^{-1}$ $\left(10^{-7} \mathrm{~mm} \mathrm{~s}^{-1}\right)$ for clayey or silty soil. ${ }^{1}$ Equation 3 shows that the infiltration rate is linearly correlated with the hydraulic conductivity. However, under an unsaturated condition, the hydraulic conductivity can vary considerably as a result of a change in the soil moisture and suction. As described in the earlier section, moisture at the ground surface increases gradually during the rainwater infiltration until the surface is saturated. At this state, $k_{\text {sat }}$ is reached. The Green-Ampt infiltration model is used to describe this phenomenon. To illustrate the effect of a change in saturated hydraulic conductivity on rainfall infiltration, Figure 6 shows the relationship between $k_{\text {sat }}$ and infiltration rate corresponding to the maximum rainfall intensity for each typhoon.
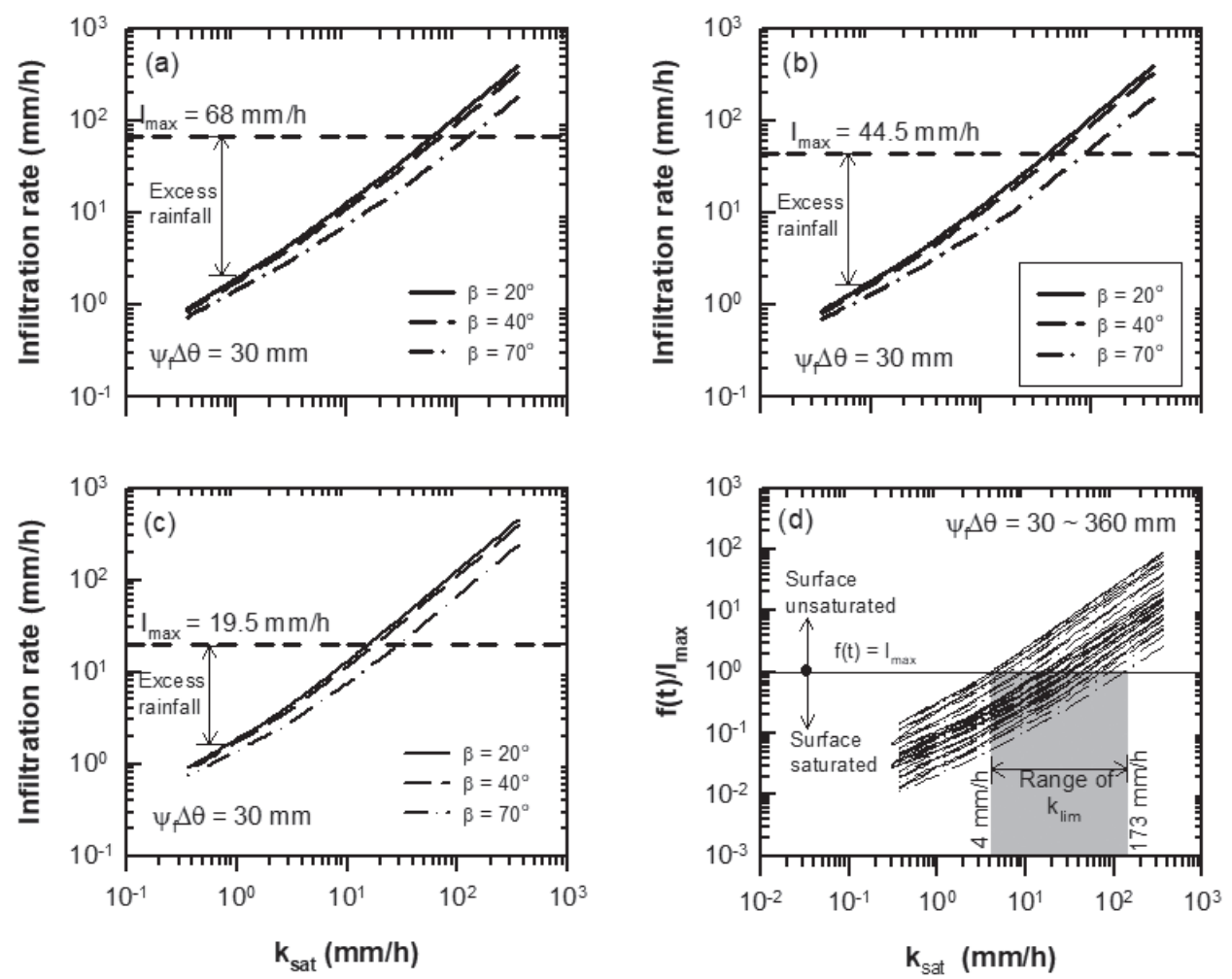

Figure 6: Change of infiltration rate with soil type for (a) Ewiniar, $\mathrm{I}_{\max }=68 \mathrm{~mm} \mathrm{~h}^{-1}$, (b) Bilis, $\mathrm{I}_{\max }=44.5 \mathrm{~mm} \mathrm{~h}^{-1}$, (c) Kaemi, $\mathrm{I}_{\max }=19.5 \mathrm{~mm} \mathrm{~h}^{-1}$, and (d) determination of $k_{\text {lim }}$. 
Figures $6(\mathrm{a}-\mathrm{c})$ show that the infiltration rate increases with the increase of the saturated hydraulic conductivity of the slope. The infiltration rate of the slope with higher permeability $\left(k_{s a t}=360 \mathrm{~mm} \mathrm{~h}^{-1}\right)$ is always higher than the maximum rainfall intensity of each typhoon. It is because of the rainfall intensity is less than the infiltration capacity equal to the saturated hydraulic conductivity. So, when the rainfall is less than the infiltration capacity, it infiltrates into the subsurface with the very higher rate. The infiltration rate will be slower if the infiltration capacity is attained. In contrast, the infiltration of soil with lower permeability, i.e., $k_{\text {sat }}=0.36-3.6 \mathrm{~mm} \mathrm{~h}^{-1}$, is always lower than the maximum rainfall intensity of each typhoon. As described in the previous section and Figure 2, surface saturation occurs if the infiltration rate is less than the rainfall intensity. Therefore, the surface starts to be saturated if the rainfall rate is equal to the rainfall intensity. At this moment, there exists a threshold of saturated hydraulic conductivity $\left(k_{\text {lim }}\right)$ corresponding to the beginning of surface saturation. Normalising the infiltration rate with the maximum rainfall intensity, Figure 6(d) plots the relationship between the normalised rainfall intensity $\left(f(t) / I_{\max }\right)$ and saturated hydraulic conductivity for various $\psi_{f} \Delta \theta$ (see Table 2) and slope angles $\beta=20^{\circ}, 40^{\circ}$ and $70^{\circ}$. Based on this relationship, the $k_{\text {lim }}$ is determined at the intersection with $f(t) / I_{\max }=1$. Thus, it results in a range of $k_{\text {lim }}=4 \mathrm{~mm} \mathrm{~h}^{-1}$ to $173 \mathrm{~mm} \mathrm{~h}^{-1}$. The wide variability of soil type decreases the accuracy of landslide timing, but it is acceptable for the global failure mode..$^{22}$

In practice, $k_{\text {lim }}$ will be a valuable parameter as an indicator of slope instability. Because of many slope failures, the slope is likely unstable if the saturation propagates deeply to the wetting front and the whole depth is saturated. The saturation will advance to the wetting front depending on the $k_{\text {sat }}$. According to the Green-Ampt equation, the depth of wetting front $\left(z_{w}\right)$ can be estimated for the given $k_{\text {sat }}$ and $\Delta \theta .^{23}$ Lowering $k_{\text {sat }}$ will also be lowering the wetting front advancement. Hence, in practical, the $k_{\text {lim }}$ can be used to determine the initial warning of slope failure due to rainfall. In this case, the surface will saturate if $f(t)=I_{\max }=k_{\text {lim }}$. As shown in Figures $6(\mathrm{a}-\mathrm{c})$ and illustration given in Figure 1, excess rainfall occurs when the slope surface is in a saturation state. This excess rainfall potentially becomes runoff which will result in surficial erosion and may cause shallow slip and limited debris flow. Rainfall might induce slope instability if $k_{\text {lim }}$ reached $3.6 \mathrm{~mm} \mathrm{~h}^{-1}\left(1 \times 10^{-6} \mathrm{~m} \mathrm{~s}^{-1}\right){ }^{1}$ A shallow slip failure is likely to occur if $k_{\text {lim }}$ ranges between $0.28 \mathrm{~mm} \mathrm{~h}^{-1}$ and $2.82 \mathrm{~mm} \mathrm{~h}^{-1}\left(7.8 \times 10^{-8}-7.8 \times 10^{-7} \mathrm{~m} \mathrm{~s}^{-1}\right){ }^{24}$ In this study, the $k_{\text {lim }}$ lays on the larger range that is between $4 \mathrm{~mm} \mathrm{~h}^{-1}$ and $173 \mathrm{~mm} \mathrm{~h}^{-1}\left(1.11 \times 10^{-6}-4.81 \times 10^{-5} \mathrm{~m} \mathrm{~s}^{-1}\right)$ for the slope angle of $20^{\circ}-70^{\circ}$. 


\subsection{Effect of Moisture-suction Head}

The $k_{\text {sat }}, \psi_{f}$ and a deficit of volumetric water content $(\Delta \theta)$ are three influencing parameters in the Green-Ampt equation to study the rainwater infiltration. The last two parameters can be aggregated in one parameter as a moisture-suction parameter $\left(M_{\psi}\right)$ since both parameters are closely related. Figure 7 shows the effect of moisture-suction on the infiltration rate for higher and lower permeability slope under three typhoons studied here.
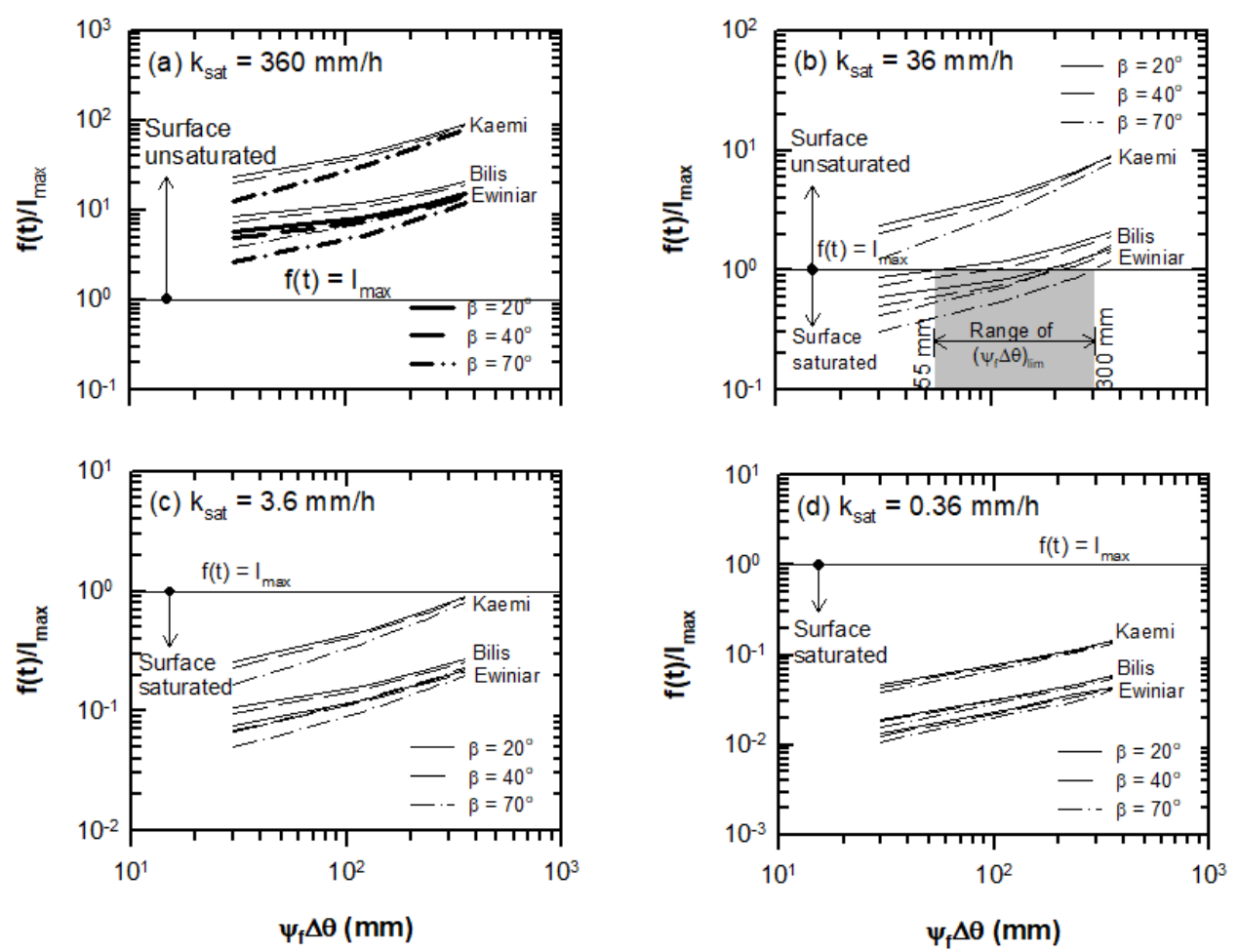

Figure 7: Change of infiltration rate with moisture-suction for (a) $k_{\text {sat }}=360 \mathrm{~mm} \mathrm{~h}^{-1}$, (b) $k_{\text {sat }}=36 \mathrm{~mm} \mathrm{~h}^{-1}$, (c) $k_{\text {sat }}=3.6 \mathrm{~mm} \mathrm{~h}^{-1}$, and (d) $k_{\text {sat }}=0.36 \mathrm{~mm} \mathrm{~h}^{-1}$.

In general, the increase of moisture-suction increases the infiltration rate linearly as shown in Figure 7. The unsaturated soil theory can explain this phenomenon. In unsaturated soil, the matrix suction $\left(u_{a}-u_{w}\right)$ is the pressure difference acting on the contractile skin of the air-water interface in the pores. During transient infiltration process, pore air is draining out, but pore water is flowing in simultaneously. The rate of pore water inflow is corresponding to the rate of pore air outflow during infiltration. ${ }^{25}$ In other words, higher suction will result in higher infiltration rate. 
The infiltration rate of the slope with lower hydraulic conductivity $\left(k_{\text {sat }}=\right.$ $0.36 \mathrm{~mm} \mathrm{~h}^{-1}$ and $3.6 \mathrm{~mm} \mathrm{~h}^{-1}$ ) increased approximately $1.2-2.0$ times by changing the moisture-suction from $30 \mathrm{~mm}$ to $360 \mathrm{~mm}$ (10 times increasing moisturesuction). For slope with a high hydraulic conductivity (i.e., $k_{\text {sat }}=36 \mathrm{~mm} \mathrm{~h}^{-1}$ and $360 \mathrm{~mm} \mathrm{~h}^{-1}$ ), the infiltration rate increased about 5-6 times when the moisturesuction of soil increased from $30 \mathrm{~mm}$ to $360 \mathrm{~mm}$. As presented in Table 1, the range of suction head $\left(\psi_{f}\right)$ for the typical soil is vast, e.g., the suction head of clay soils in the range of $63.9 \mathrm{~mm}$ to $565 \mathrm{~mm}$ ( \pm 25 times increasing of suction head), and sand soils is $9.7-253.6 \mathrm{~mm}$ ( \pm 26 times increasing suction head). In this study, the suction head was in the range of 100-1200 mm (12 times increasing), the infiltration rate of a sand soil significantly varied if compared with clay soils. Parameter sensitivity analysis of Green-Ampt model found that change in the suction head increased considerably for loam and sandy soils. ${ }^{3,26}$ However, it was contrary to clay soils. Therefore, determination of the suction head in the GreenAmpt model should be well defined. The suction head at the wetting-front can be approached by air entry value (AEV). ${ }^{27,28}$ However, the suction head at the wetting front was close to zero at the moment of the saturated condition. For some soils, the suction value near saturation could not be well defined. For this reason, the average suction head is proposed to represent suction at the wetting front. ${ }^{29,30}$

As mentioned in the previous section, the slope surface starts to saturate if the slope infiltration rate is the same as rainfall intensity. In Figure 7(b), for $k_{\text {sat }}=36 \mathrm{~mm} \mathrm{~h}^{-1}$ under typhoon Ewiniar and Bilis, the slope was in unsaturated states at the beginning and tended to be saturated by decreasing the moisturesuction from $360 \mathrm{~mm}$ to $30 \mathrm{~mm}$. In this case, the slope surface started to saturate when the moisture-suction $\left(M_{\text {lim }}\right)$ in the range of $55 \mathrm{~mm}$ to $300 \mathrm{~mm}$. This phenomenon explains that the change in moisture-suction not only changes the infiltration rate but also affects the degree of slope surface saturation. Therefore, the moisture-suction value should be well defined by relevant data or tests. However, it should be noted that the determination of the suction is a rather complicated process, even if the data is available. ${ }^{31,32}$

\section{CONCLUSION}

This paper has presented the result of rainfall infiltration analysis on the sloping surface using Green-Ampt infiltration model. The study analysed the effect of slope angle, soil type and moisture-suction on the Green-Ampt infiltration model. A new graphical aid has been developed to represent the basic GreenAmpt equation for the sloping surface. The study concluded that increasing slope steepness reduces the rainwater infiltration rate. Comparing the infiltration for 
sloping surface and horizontal surface, the reduction of infiltration rate is given by $k_{\text {sat }}(1-\cos \beta)$. The infiltration rate increased linearly with the increasing saturated hydraulic conductivity of the slope. The infiltration rate of the slope with higher permeability was always higher in the soil with lower permeability. The increase in the moisture-suction parameter at the wetting-front increased the infiltration during the rainfall. Change in moisture-suction increased the infiltration rate of the slope with high permeability such as sand soils comparing with a slope with a low permeability such clay considerably. This research proposed the maximum rainfall intensity $\left(I_{\max }\right)$ to determine the threshold of saturated hydraulic conductivity $\left(k_{\text {lim }}\right)$ and moisture-suction $\left(M_{\text {lim }}\right)$ that induced saturation at the surface. In this case, the slope surface started to saturate when the $k_{\text {lim }}$ was in the range of $1.11 \times 10^{-6} \mathrm{~m} \mathrm{~s}^{-1}$ to $4.81 \times 10^{-5} \mathrm{~m} \mathrm{~s}^{-1}$, and $M_{\text {lim }}$ in the range of $0.055 \mathrm{~m}$ to $0.300 \mathrm{~m}$.

\section{ACKNOWLEDGEMENTS}

This research is supported by Ministry of Research, Technology, and Higher Education through Competence-based Research grant DIPA-042.06.0.1. 401516/2016. The authors fully acknowledge Universitas Muhammadiyah Yogyakarta, Indonesia for the approved fund of the International Collaborative Research grant making this important research viable and useful.

\section{REFERENCES}

1. Pradel, D. \& Raad, G. (1993). Effect of permeability on surficial stability of homogeneous slopes. J. Geotech. Eng., 119(2), 315-332, https://doi.org/10.1061/ (ASCE)0733-9410(1993)119:2(315).

2. Rahardjo, H. et al. (1995). Shear strength characteristics of a residual soil. Can. Geotech. J., 32, 60-77, https://doi.org/10.1139/t95-005.

3. Hsu, S. M., Ni, C. F. \& Hung, P. F. (2002). Assessment of three infiltration formulas based on model fitting on Richards equation. J. Hydrol. Eng., 7(5), 373379, https://doi.org/10.1061/(ASCE)1084-0699(2002)7:5(373).

4. Ma, Y. et al. (2010). Modeling water infiltration in a large layered soil column with a modified Green-Ampt model and HYDRUS-1D. Comp. Electr. Agric., 71, S40-S47. https://doi.org/10.1016/j.compag.2009.07.006.

5. Muntohar, A. S. \& Ikhsan, J. (2013). Development of a simple model for preliminary evaluation on extreme rainfall induces shallow slope failure. Paper presented at the Proceeding of the 13th International Conference on Quality in Research (QIR), Yogyakarta, Indonesia, 25-28 June.

6. Gowdish, L. \& Carpena, R. M. (2009). An improved Green-Ampt infiltration and redistribution method for uneven multistorm series. Vadose Zone J., 8, 470-479. 
7. Ma, Y. et al. (2011). Water infiltration in layered soils with air entrapment: Modified Green-Ampt model and experimental validation. J. Hydrol. Eng., 16(8), 628-638, https://doi.org/10.1061/(ASCE)HE.1943-5584.0000360.

8. Liu, J., Zhang, J. \& Feng, J. (2008). Green-Ampt model for layered soils with nonuniform initial water content under unsteady infiltration. Soil Sci. Soc. Am. J., 72, 1041-1047, https://doi:10.2136/sssaj2007.0119.

9. Xie, M. W., Esaki, T. \& Cai, M. F. (2004). A time-space based approach for mapping rainfall-induced shallow landslide hazard. Environ. Geol., 46, 840-850, https://doi.org/10.1007/s00254-004-1069-1.

10. Tofani, V. et al. (2006). Infiltration, seepage and slope instability mechanisms during the 20-21 November 2000 rainstorm in Tuscany, central Italy. Nat. Haz. Earth Syst. Sci., 6, 1025-1033, https://doi.org/10.5194/nhess-6-1025-2006.

11. Zhang, X. C., Nearing, M. A. \& Risse, L. M. (1995). Estimation of Green-Ampt conductivity parameters. Part I: Row crops. Trans. ASAE, 38(4), 1069-1077.

12. Clausnitzer, V., Hopmans, J. W. \& Starr, J. L. (1998). Parameter uncertainty analysis of common infiltration models. Soil Sci. Soc. Am. J., 62, 1477-1487, https://doi:10.2136/sssaj1998.03615995006200060002x.

13. Chu, T. C. (1978). Infiltration during an unsteady rain. Water Resour. Res., 14(3), 461-466.

14. Cui, G. T. \& Zhu, J. T. (2017). Infiltration model in sloping layered soils and guidelines for model parameter estimation. Hydrol. Sci. J., 62(13), https://doi.org/ 10.1080/02626667.2017.1371848.

15. Chen, L. \& Young, M. H. (2006). Green-Ampt infiltration model for sloping surface. Water Resour. Res., 42, 1-9, https://doi.org/10.1029/2005WR004468.

16. Lu, H. S., Hu, S. C. \& Lin, J. P. (1996). Infiltration model for soils on a sloping betel palm farm in the Lienhuachi area of Central Taiwan. J. For. Sci., 11(4), 409-420.

17. Fox, D. M., Bryan, R. B. \& Price, A. G. (1997). The influence of slope angle on final infiltration rate for interrill conditions. Geod., 80, 181-194, https://doi. org/10.1016/S0016-7061(97)00075-X.

18. Muntohar, A. S. \& Liao, H. J. (2010). Rainfall infiltration-infinite slope model for landslides triggered by rainstorm. Nat. Haz., 54(3), 967-984, https://doi. org/10.1007/s11069-010-9518-5.

19. Muntohar, A. S. \& Liao, H. J. (2009). Analysis of rainfall induced infinite slope failure during typhoon using a hydrological-geotechnical model. Environ. Geol., 56(1), 1145-1159, http://dx.doi.org/10.1007/s00254-008-1285-1.

20. Rawls, W. J. et al. (1993). Infiltration and soil water movement. In Maidment, D. R. (ed.), Handbook of hydrology. New York: McGraw-Hill, 1-51.

21. Chow, V. T., Maidment, D. R. \& Mays, L. W. (1988). Applied hydrology. New York: McGraw-Hill.

22. Fan, L., Lehmann, P. \& Or, D. (2016). Effects of soil spatial variability at the hillslope and catchment scales on characteristics of rainfall-induced landslides. Water Resour. Res., 52, 1781-1799, https://doi.org/10.1002/2015WR017758.

23. Sun, H. W., Wong, H. N. \& Ho, K. K. S. (1998). Analysis of infiltration in unsaturated ground. In Li, K. S., Kay, J. N. \& Ho, K. K. S. (eds.), Slope engineering in Hong Kong. Rotterdam: Balkema, 101-109. 
24. Lee, K. H., Jeong, S. S. \& Kim, T. H. (2007). Effect of fines on the stability of unsaturated soil slopes. J. Kor. Geotech. Soc., 23(3), 101-109.

25. Wang, Z. et al. (1998). Air entrapment effect on infiltration rate and flow instability. Water Resour. Res., 34(2), 213-222, https://doi.org/10.1029/97WR02804.

26. Gavin, K. \& Xue, J. (2008). A simple method to analyze infiltration into unsaturated soil slopes. Comp. Geotech., 35(2), 223-230, https://doi.org/10.1016/j. compgeo.2007.04.002.

27. Lu, N. \& Likos, W. J. (2004). Rate of capillary rise in soil. J. Geotech. Geoenviron. Eng., 130(6), 646-650, https://doi.org/10.1061/(ASCE)10900241(2004)130:6(646).

28. Wang, X. D. \& Benson, C. H. (1995). Infiltration and saturated hydraulic conductivity of compacted clay. J. Geotech. Eng., 121(10), 713-722, https://doi. org/10.1061/(ASCE)0733-9410(1995)121:10(713).

29. Mein, R. G. \& Larson, C. L. (1973). Modeling infiltration during a steady rain. Water Resour. Res., 9(2), 384-394, https://doi.org/10.1029/WR009i002p00384.

30. Santos, C. A. G. et al. (1999). Determining the soil moisture-tension parameter in the Green-Ampt infiltration equation for runoff-erosion modelling. Paper presented at the Proceeding of the 28th IAHR Congress, Graz, Austria, 22-27 August, 231240.

31. Nam, S. et al. (2009). Comparison of testing techniques and models for establishing the SWCC of riverbank soils. Eng. Geol., 110(1-2), 1-10, https://doi.org/10.1016/j. enggeo.2009.09.003.

32. Haghizadeh, A., Soleimani, L. \& Zeinivand, H. (2014). Optimization of the conceptual model of Green-Ampt using artificial neural network (ANN) model and WMS to estimate infiltration rate of soil (Case Study, Kakasharaf Watershed, Khorram Abad, Iran). J. Water Resour. Prot., 6(5), Article ID,45305, https://doi. org/10.4236/jwarp.2014.65047. 